\title{
Potential of Calliandra calothyrsus Leaf Extract to Maintain Estrogen Concentration and Uterine Thickness in Rats
}

\author{
Iriani Setyawati*, Ni Nyoman Wirasiti, Luh Putu Eswaryanti Kusuma Yuni \\ Program Study of Biology, Faculty of Mathematics and Natural Sciences, Universitas Udayana, Indonesia \\ *Corresponding Author: iriani_setyawati@unud.ac.id
}

Submitted: 2021-07-06. Revised: 2021-07-21. Accepted: 2021-08-13

\begin{abstract}
Calliandra calothyrsus Meissn. leaf extract is potential as phytoestrogens. It influenced male mice reproduction, rat estrous cycle, and ovarian histology in previous study. This research aimed to prove the $C$. calothyrsus leaf extract potential as phytoestrogen source and the effect on endometrial thickness where the embryo implantation take place in early pregnancy. This study used a Completely Randomized Design used 54 days old female rats (Rattus norvegicus). Rats were divided into K as control group (treated with $0.5 \% \mathrm{Na}-\mathrm{CMC}$ as placebo) and $\mathrm{P} 1, \mathrm{P} 2$, and $\mathrm{P} 3$ as three groups with $C$. calothyrsus leaf extract administration with doses of 17.5 ; 35 ; and $70 \mathrm{mg} / \mathrm{kg}$ bw respectively. Treatments were given $1 \mathrm{ml} / \mathrm{rat} /$ day orally for 20 days. At day $21^{\text {st }}$, animals were euthanized to collect blood samples for estrogen hormone analysis. After the dissection, all uterus were collected and weighed. Histological preparation was done with paraffin method and Hematoxylin-Eosin staining. The effective dose was $70 \mathrm{mg} / \mathrm{kg}$ bw that did not decrease the weight of the uterus and the body. This dose even maintained the normal diameter and thickness of uterine walls (endometrium, myometrium, and perimetrium layers) like control rats. The extract in this study could increase estrogen concentration in female rats. This research novelty is that $C$. calothyrsus leaf extract $(70 \mathrm{mg} / \mathrm{kg}$ bw) can be used as an alternative herbal suplement to maintain uterine wall thickness and estrogen concentration in productive women. With further clinical research, this extract is expected to be a potential estrogen source to overcome women infertility or pregnancy difficulties due to problem of endometrial thickness and lack of endogenous estrogen.
\end{abstract}

Key words: Calliandra calothyrsus; estrogen; endometrium; myometrium; perimetrium

How to Cite: Setyawati, I., Wirasiti, N. N., \& Yuni, L. P. E. K. (2021). Potential of Calliandra calothyrsus Leaf Extract to Maintain Estrogen Concentration and Uterine Thickness in Rats. Biosaintifika: Journal of Biology \& Biology Education, 13(2), $230-236$.

DOI: http://dx.doi.org/10.15294/biosaintifika.v13i2.31063

\section{INTRODUCTION}

Estrogen is important for reproduction of both male and female, and also affect other systems including circulatory, immune, neuroendocrine, and skeletal systems. This hormon is also implicated in many conditions, disorders or diseases such as endometriosis, infertility, cancers, osteoporosis, and obesity (Hamilton et al., 2017). Estrogen is very important in female reproductive organs such as estrus cycle and ovulation (Barrett et al., 2019). Estrogen stimulates epiphyseal bone growth and maturation. Lack of estrogen can cause problems in female reproduction that reduce fertility such as menstrual cycle irregularities (Hall, 2015), delay uterine development, and induce atrophy and inactive myometrium (Barrett et al., 2019).

Phytoestrogens are generally consumed by reproductive women who experience reproductive disorders and fertility problems because of their ability to launch menstrual cycle and maintain fertility. Phytoestrogens are also efficacious for reducing menopause symptoms (Widhayanthi et al., 2017). To overcome the problem of lacking endogenous estrogen in the body, various studies of phytoestrogens effects on adult females reproduction have been carried out to explore sources of exogenous estrogen.

Several compounds from plants have estrogenic properties, such as isoflavones, lignans, coumestan, and lactones (Roberts \& Lethaby, 2014). Calliandra calothyrsus Meissn. contains flavonoids, quercetin, saponins, caffeic acid, alkaloids, tannins, and phytosterol (Onyeama et al., 2012; Setyawati et al., 2019). C. calothyrsus leaf extract shortened the proestrus and estrus phases, and caused an increased number of corpus luteum in rat's ovary (Mardika et al., 2018).

This study aimed to further examine phytoestrogen potential of $C$. calothyrsus leaf extract on changes in uterine weight and histology of rat, as well as blood estrogen concentration. If estrogen concentration increase in the body, it will increase uterine growth and development as vital reproductive organ (the womb) for attachment and development of embryo during pregnancy. Women can harness $C$. calothyrsus leaf extract to maintain uterine wall thickness and estrogen concentration during pregnancy particularly the implantation period. 


\section{METHODS}

\section{C. calothyrsus leaf extract preparation}

The study used fresh C. calothyrsus leaves (dark green colour), obtained from Mekarsari area, Baturiti Bedugul, Tabanan, Bali. Leaves were harvested in the morning, washed with running water and air-dryed for 7 days. Dried leaves were blended into powder. A total of $500 \mathrm{~g}$ of $C$. calothyrsus leaf powder was macerated using $2500 \mathrm{ml}$ of $\mathrm{N}-\mathrm{Hexane}$ at room temperature for one day then filtered (this activity were repeated twice). After that, the macerate was digested with $2500 \mathrm{ml}$ ethanol $80 \%$ for 2 hours and filtered (this activity were repeated twice). The macerate was evaporated with a vacuum rotary evaporator $\left(50^{\circ} \mathrm{C}\right)$, and oven-dryed $\left(40^{\circ} \mathrm{C}\right)$. Then the crude extract was weighed.

The suspension of $0.5 \% \mathrm{CMC} \mathrm{Na}$ was made by adding $50 \mathrm{mg}$ of CMC Na on warm water in a mortar and grounded until homogeneous. The mixture was put into a $100 \mathrm{ml}$ volumetric flask and added with distilled water up to $100 \mathrm{ml}$. Suspension of $0.5 \%$ CMC Na was administered to the control rats.

\section{Animal handling}

Before starting the research, an ethical clerance was evaluated by the Ethics Commission of Animal Use for Education and Research, Faculty of Veterinary Medicine, Udayana University. Forty female rats (Rattus norvegicus) were 54 days old at study initiation. Rats should be healthy and move actively without physical defects and tumors. Rats were given water (ad libitum) and fed with standard concentrate feed (CP 551) produced by PT Charoen Pokphand Indonesia. Rats were kept in plastic cages, with wire mesh cover on the top and husks at the bottom of the cage to absorb urine and feces. The cages were placed in a room with $27^{\circ} \mathrm{C}$ temperature, $50-60 \%$ relative humidity, and lighting cycle (12 hours light and 12 hours darkness). Rats body weight were weighed every day, as a basis for determining the volume of the given extract.

\section{Extract treatment on female rats}

This study used a completely randomized design with four treatments namely $\mathrm{K}$ as control (placebo), and treatment with extract doses of $17.5 \mathrm{mg} / \mathrm{kg}$ bw (P1), $35 \mathrm{mg} / \mathrm{kg}$ bw (P2), and $70 \mathrm{mg} / \mathrm{kg}$ bw (P3). Forty female rats (Rattus norvegicus) were divide into four groups. Treatments were administered once daily (1 $\mathrm{ml}$ for each rat) on days 1 to 20 by oral gavage. Rats were euthanized on day 21 , and the blood samples were taken through the retroorbital plexus using microcapillaries. The uterus was weighed and put in $10 \%$ neutral-buffered formalin (fixative agen), then processed for histological slide.

\section{Estrogen hormone analysis}

Blood samples were collected in Eppendorf tube and centrifuged at $3000 \mathrm{rpm}$ for 10 minutes. Fifty ml of serum was taken and added with $500 \mu 1$ of uranyl acetate for deproteinization. Samples were centrifuged at $3000 \mathrm{rpm}$ for 5 minutes, then $500 \mu \mathrm{l}$ of the supernatant was taken. Estrogen concentrations were measured using the ELISA commercial kit, then read with ELISA spectrophotometer at $450 \mathrm{~nm}$ wavelength. Results are expressed in units of $\mathrm{pg} / \mathrm{mL}$.

\section{Uterine weight and histology}

All uterus were collected, washed with $0.9 \% \mathrm{NaCl}$ saline, dried using Whatman paper, weighed, and fixed in $10 \%$ Neutral-Buffered Formalin. The sectioning was made one from the uterine body and three from each uterine horn for each animal. One Hematoxylin and Eosin (H\&E)-stained slide was prepared from each paraffin block for microscopic observation (Schweikart et al., 2014). We used Optilab Viewer software for microscopic photos, and Image Raster software for histological observations.

\section{Data analysis}

The data were presented as mean and deviation standard. Kolmogorov-Smirnov normality test, Leven's Test, and One Way ANOVA with Duncan's post hoc tests were used to test estrogen concentrations, uterine weight, and uterine wall thickness (uterine diameter and thickness of endometrium, myometrium, and perimetrium) statistically. A $p$ value of $\leq 0.05$ was considered statistically significant.

\section{RESULTS AND DISCUSSION}

\section{Effect of $C$. calothyrsus on blood estrogen concentration}

Rat estrogen concentrations showed significant difference $(\mathrm{P}<0.05)$ after the administration of all extract doses compared to the control. However, there was no significant difference $(\mathrm{P}>0.05)$ between $\mathrm{P} 2$ and P3 (Table 1).

Table 1. Estrogen concentrations of female rat treated with Calliandra calothyrsus leaf extract.

\begin{tabular}{cc}
\hline Treatments & Estrogen concentrations $(\mathrm{pg} / \mathrm{mL})$ \\
\hline K & $36.09 \pm 1.295^{\mathrm{a}}$ \\
P1 & $49.85 \pm 1.710^{\mathrm{c}}$ \\
P2 & $45.33 \pm 4.933^{\mathrm{b}}$ \\
P3 & $44.40 \pm 1.267^{\mathrm{b}}$ \\
\hline
\end{tabular}

Different superscript letters following the value (mean $\pm \mathrm{SD}$ ) in the same column indicate significant difference $(\mathrm{P}<0.05)$. K: control, $\mathrm{P} 1$ : C. calothyrsus 
extract of $17.5 \mathrm{mg} / \mathrm{kg}$ bw, P2: C. calothyrsus extract of $35 \mathrm{mg} / \mathrm{kg}$ bw, P3: C. calothyrsus extract of 70 $\mathrm{mg} / \mathrm{kg}$ bw.

In this study, administration of $C$. calothyrsus leaf extract increased estrogen (estradiol) hormone concentrations. The highest increase in estrogen concentration was found in P1. The value was significantly different from P2 and P3. However, all doses of extract could increase estrogen concentrations significantly $(\mathrm{P}<0.05)$ compared to control rats (Table 1).

C. calothyrsus leaf extract contains alkaloids, flavonoids, polyphenols, anthraquines, and 2hydroxy-4-methoxy benzoic acid (Onyeama et al., 2012). Flavonoid (especially isoflavones), saponins and alkaloids can stimulate the formation of estrogen in mammals. From their structure, there are similarities with the estrogen hormone (Resende et al., 2013). These compounds make $C$. calothyrsus a potential phytoestrogen source.

In females, estrogen increase reproductive performance by stimulating uterine growth to increase endometrial and myometrial mass. Estrogen also stimulates uterine contractility, vaginal epithelium proliferation and differentiation, mammary gland ducts development, and influences secondary genitalia development (Gultom, 2001).

Phytoestrogens are able to recognize and bind to estrogen receptors, ERs, found in the nuclear membrane and plasma membrane in target organs, and have almost the same activity with estrogen in the body. Two types ERs in the body, alpha (ER $\alpha)$ and beta $(\mathrm{ER} \beta)$, are expressed in cells and tissues. They play roles in many organ physiological functions, such as reproduction, cardiovascular, skeletal, and central nervous systems, especially in breast, ovary and prostate. ER $\alpha$ is found mainly in breast, womb, thecal cells of the ovary, bone, stroma of prostate, testes, epididymis, liver, and adipose tissue. ER $\beta$ is present mainly in adipose tissue, immune system, colon, bladder, prostate epithelium, and granulosa cells of the ovary (Paterni et al., 2014).

The structure of phytoestrogens are very similar to endogenous estrogen and are able to bind with ER $\alpha$ and ER $\beta$ (Paterni et al., 2014). ER $\alpha$ act in cell proliferation, whereas ER $\beta$ are responsible for cell apoptosis (Rietjens et al., 2013). Phytoestrogens are competitors for endogenous estrogen to occupy estrogen receptors so that natural estrogens cannot bind to their receptors and will result in an increase in the amount of free estrogen. This bond increases ovarian follicle cells proliferation including theca cells. It will increases estrogen produced by the inner theca cells. The effect of phytoestrogens depend on the concentration of endogenous estrogen (estradiol), because phytoestrogens and estrogens compete to bind to ERs. When endogenous estrogen is high, it can inhibit estrogen activity by occupying part of the ERs (Lephart, 2015). The clinical implications of phytoestrogens depend on several factors such as number of receptors that can bind to phytoestrogens, location of ERs, and estrogen concentration that can compete with phytoestrogens.

\section{Effect of $\boldsymbol{C}$. calothyrsus on uterine weight}

The uterus is an organ that is very responsive to estrogen changes. Estrogen has a main function in the uterus, which is to play a role in cell proliferation and tissue growth related to reproductive function. Estrogen is secreted in small amounts in childhood and increases with puberty. Estrogen will increase in amount under the influence of gonadotropin hormones. Stimulation of this increased gonadotropin hormone will make the ovaries, uterus, vagina and fallopian tubes increase in size. During puberty, there is an increase in uterus size and changes in endometrium, then there is stromal proliferation and an increase in endometrial glands development (Hall, 2015).

In this study, the highest uterine weight was found at the P3 which was not significantly different with the control. However, P1 and P2 actually caused uterine weight decrease significantly (Table 2). Administration of $C$. calothyrsus leaf extract did not cause a significant increase in uterine wet weight. Although estrogen causes marked proliferation of the uterus according to Hall (2015), phytoestrogens are weak agonists for the body's estrogen receptors. In addition, differences in body weight are also one of the factors that can cause differences in uterine weight.

Table 2. Uterine weight of female rat treated with Calliandra calothyrsus leaf extract.

\begin{tabular}{cl}
\hline Treatments & Uterine weight $(\mathrm{g})$ \\
\hline $\mathrm{K}$ & $0.272 \pm 0.071^{\mathrm{b}}$ \\
$\mathrm{P} 1$ & $0.101 \pm 0.033^{\mathrm{a}}$ \\
P2 & $0.143 \pm 0.038^{\mathrm{a}}$ \\
P3 & $0.290 \pm 0.035^{\mathrm{b}}$ \\
\hline
\end{tabular}

Different superscript letters following the value (mean $\pm \mathrm{SD}$ ) in the same column indicate significant difference $(\mathrm{P}<0.05)$. K: Control, $\mathrm{P} 1$ : C. calothyrsus extract of $17.5 \mathrm{mg} / \mathrm{kg}$ bw, P2: C. calothyrsus extract of $35 \mathrm{mg} / \mathrm{kg}$ bw, P3: C. calothyrsus extract of 70 $\mathrm{mg} / \mathrm{kg}$ bw.

Estrogen is a hormone that can cause fluid accumulation and vascularization, growth and activity of the endometrium and prepares for progesterone action on endometrium (Thiyagarajan et al., 2020). Uterine weight decrease in treated rats at P1 and P2 (Table 2) was thought because these doses inhibited 
the anterior pituitary from secreting FSH and LH so that the concentrations of estrogen in the blood decreased. We assumed that the presence of terpenoids, saponins and tannins at certain doses is apparently adequate cause of negative feedback on release of gonadotropin.

At certain doses, phytoestrogens as exogenous estrogens from outside the body, can cause a significant change in uterine weight in an uterotrophic bioassay study. Some factors may be involved in causing uterine weight differences, such as estrogen agonist properties, cell proliferation, route of drug exposure, vascular permeability, water retention, and also animal strain (Schweikart et al., 2014).

\section{Effect of $C$. calothyrsus on uterine wall thickness}

The uterus showed a significant decrease in diameter in P1 and P2 compared to control. Meanwhile, the P3 did not show significant decrease $(\mathrm{P}>0.05)$ although the largest diameter (which means the thickest uterine wall) remained in the control rats (Table 3).

Table 3. Uterine diameter of female rat treated with Calliandra calothyrsus leaf extract.

\begin{tabular}{cl}
\hline Treatments & Uterine diameter $(\mu \mathrm{m})$ \\
\hline $\mathrm{K}$ & $553.75 \pm 114.359^{\mathrm{c}}$ \\
$\mathrm{P} 1$ & $397.65 \pm 45.961^{\mathrm{a}}$ \\
$\mathrm{P} 2$ & $423.01 \pm 64.241^{\mathrm{ab}}$ \\
$\mathrm{P} 3$ & $512.61 \pm 55.610^{\mathrm{bc}}$ \\
\hline
\end{tabular}

Different superscript letters following the value (mean $\pm \mathrm{SD}$ ) in the same column indicate significant difference $(\mathrm{P}<0.05)$. K: Control, $\mathrm{P} 1$ : C. calothyrsus extract of $17.5 \mathrm{mg} / \mathrm{kg}$ bw, P2: C. calothyrsus extract of $35 \mathrm{mg} / \mathrm{kg}$ bw, P3: C. calothyrsus extract of 70 $\mathrm{mg} / \mathrm{kg}$ bw.

The results of rat uterine wall thickness showed that endometrium thickness of $\mathrm{K}$ group was not significantly different compared to $\mathrm{P} 3$, while they showed a significant difference $(\mathrm{P}<0.05)$ compared to $\mathrm{P} 1$ and P2. Different things were seen in the myometrium and perimetrium thickness, only rats from the P1 showed significantly different results $(\mathrm{P}<0.05)$ compared to the control (Table 4).

In our study, the increase dose of $C$. calothyrsus leaf extract made the increase thickness of uterus' wall in all three layers (Table 4). The highest dose 70 $\mathrm{mg} / \mathrm{kg}$ bw of C. calothyrsus leaf extract (P3) gave the thickest wall of endometrium, myometrium and perimetrium among the extract treatments $(\mathrm{P} 1, \mathrm{P} 2$, P3). However, this effect was not significant compared to the control (K) (Table 4).

Table 4. Thickness of the uterine wall layers of rats given $C$. calothyrsus leaf extract

\begin{tabular}{cccc}
\hline $\begin{array}{c}\text { Treatm } \\
\text { ents }\end{array}$ & $\begin{array}{c}\text { Endometrial } \\
\text { thickness } \\
(\mu \mathrm{m})\end{array}$ & $\begin{array}{c}\text { Myometrial } \\
\text { thickness } \\
(\mu \mathrm{m})\end{array}$ & $\begin{array}{c}\text { Perimetrial } \\
\text { thickness } \\
(\mu \mathrm{m})\end{array}$ \\
\hline \multirow{2}{*}{$\mathrm{K}$} & $300.85 \pm$ & $112.53 \pm$ & $140.37 \pm$ \\
& $75.724^{\mathrm{b}}$ & $28.397^{\mathrm{b}}$ & $20.832^{\mathrm{b}}$ \\
$\mathrm{P} 1$ & $191.35 \pm$ & $87.51^{ \pm}$ & $118.79^{\mathrm{a}} \pm$ \\
& $46.504^{\mathrm{a}}$ & $13.268^{\mathrm{a}}$ & $10.571^{\mathrm{a}}$ \\
$\mathrm{P} 2$ & $204.01^{\mathrm{a}}$ & $97.96^{\mathrm{a}}$ & $121.04^{\mathrm{ab}}$ \\
& $67.363^{\mathrm{a}}$ & $9.614^{\mathrm{ab}}$ & $15.756^{\mathrm{ab}}$ \\
$\mathrm{P} 3$ & $280.46^{\mathrm{a}}$ & $99.80^{\mathrm{a}}$ & $131.78^{\mathrm{ab}}$ \\
\hline & $40.562^{\mathrm{b}}$ & $14.967^{\mathrm{ab}}$ & $16.809^{\mathrm{ab}}$ \\
\hline
\end{tabular}

Different superscript letters folowing the value (mean $\pm \mathrm{SD}$ ) in the same column indicate significant difference $(\mathrm{P}<0.05)$. K: Control, $\mathrm{P} 1$ : C. calothyrsus extract of $17.5 \mathrm{mg} / \mathrm{kg}$ bw, P2: C. calothyrsus extract of $35 \mathrm{mg} / \mathrm{kg}$ bw, P3: C. calothyrsus extract of 70 $\mathrm{mg} / \mathrm{kg}$ bw.

Uterus is the main reproductive organ of female mammals for blastocyst implantation. Many female fertility problems are of uterine origin (AbdElkareem, 2017). Uterus comprises three layers such as endometrium, myometrium and perimetrium. Endometrium as the inner lining, composes of superficial and basal part. The superficial layer is sensitive to female reproduction hormones. The outer layer, perimetrium/serosa, consists of epithelial cells. Myometrium, the midle part, is a thick muscular layer consists of smooth muscle cells (Ameer et al., 2021). Human endometrial glands secrete bioactive substances necessary for uterine receptivity by regulating uterine receptivity genes and glandspecific genes. The substances also regulate homeostasis of uterine luminal fluid (ULF) for blastocyst implantation. Uterine glands in the endometrium produce and secrete substances essential for survival and development of the conceptus (embryo and extraembryonic membranes) (Kelleher et al., 2016).

In overall development of the uterus, estrogen plays an important role in uterine proliferation, especially endometrium proliferation (Chung et al., 2015). To find out more about the effect of phytoestrogens on the uterine organs of rats, an analysis of the histological structure of the uterus was performed, which can be seen in Figure 1. 


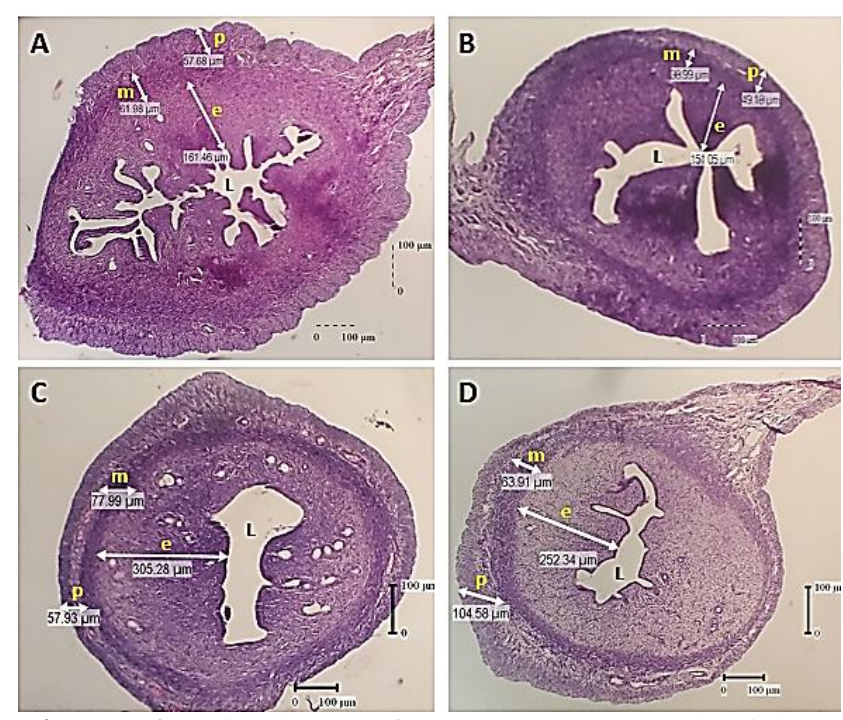

Figure 1. Histology of rat uterus treated with $C$. calothyrsus leaf extract. A. K (control), given NaCMC 0.5\%; C. calothyrsus doses B. $17.5 \mathrm{mg} / \mathrm{kg}$ bw (P1), C. $35 \mathrm{mg} / \mathrm{kg}$ bw (P2), D. $70 \mathrm{mg} / \mathrm{kg}$ bw (P3); $\mathrm{L}=$ lumen, $\quad \mathrm{e}=$ endometrium, $\mathrm{m}=$ myometrium, $\mathrm{p}=$ perimetrium, (scale bar $200 \mu \mathrm{m}$, magnification $50 \times)$.

Changes in the uterine endometrium were indicated by changes in the size of endometrium thickness (Tables 4 and Figures 1). In female reproductive organ, alpha estrogen receptor $(\mathrm{ER} \alpha)$ is mainly present in uterus, breast, thecal cells of ovary, while beta estrogen receptor (ER $\beta$ ) is mainly present in granulosa cells of ovary (Paterni et al., 2014). ER $\alpha$ plays vital role to the uterus. ER $\alpha$ has cell type dependent roles. It molecular roles in normal function of the uterus are important to study the disturbance that conduct embryo implantation or cause endometrial diseases (Hamilton et al., 2017).

$\mathrm{ER} \alpha$ activation in the uterus provokes cell proliferation, which is imperative for the growth and maintenance of tissues (Thomas \& Gustafsson, 2011). Endometrium layer comprises luminal and glandular epithelial cells with stromal cells surround, together comprising the uterine innermost layer. Uterus supports fertility while its endometrium receives embryo then facilitates implantation and decidualization process. Endometrium supports the growth and development of embryo until the placenta is formed (Marquardt et al., 2019). The research of Narulita et al. (2016), proved that the induction of synthetic estrogen hormone increases estradiol concentrations and significantly affects the thickening of the endometrium in the diestrus phase.

Estrogen has the power to prevent Follicle Stimulating Hormone (FSH) production and stimulate Luteinizing Hormone (LH) production. When estrogen concentrations reach a certain concentration, then LH is released from the anterior pituitary, $\mathrm{LH}$ concentrations in the blood suddenly increase until ovulation occurs. After ovulation occurs, LH concentrations decrease rapidly but not to a minimum, but enough to stimulate the theca interna cells in the follicle to form the corpus luteum (Kumar $\&$ Sait, 2011). The corpus luteum will produce the hormone progesterone, which reduces estrogen activity (Holesh et al., 2021).

C. calothyrsus leaf extract contains phytoestrogen, flavonoid, which have an $\mathrm{OH}$ group. The composition of flavonoid contained in $C$. calothyrsus leaf extract was thought to be similar to endogenous estrogen (Setyawati et al., 2019), so that it was able to bind to estrogen receptors (ERs) on target cells that affect the number of glands and the thickness of the endometrial layer.

The mechanism of estrogen hormone synthesis that can affect endometrium thickness is through estrogen synthesis in endometrium cells. Estrogen activity in cells occurs when estrogen binds to ERs, then activates the receptor to bind to the binding site on the DNA chain. DNA that binds to ERs stimulates synthesis and expression of mRNA in the form of protein synthesis so that target cell activity increases, and proliferation occurs (Johnson, 2018). Epithelial proliferation and protection decrease without the action of estrogen (Constantine et al., 2019).

The homeostasis of endometrium is connected with estrogen and progesteron signaling. Regulation of estrogen and progesteron pathways are very important for fertility and uterine function. If dysregulation of the pathways happens, some pathologies such as endometriosis and infertility may occur. Regulators and modulators signaling of estrogen and progesteron play important role to maintain the endometrial gene regulatory networks (Marquardt et al., 2019).

Estrogens also promote a series of myometrial changes that allow coordinated uterine contractions in parturition process. These changes include increase production of prostaglandins, oxytocin receptor expression, $\alpha$ adrenergic agonist (modulator of membrane calcium channels), connexin synthesis and formation of gap junction inside myometrium layer, and enzyme upregulation which is necessary for muscle contraction (Kota et al., 2013).

Phenolic compound is the largest antioxidants contributor in C. calothyrsus leaf extract. The IC 50\% value of $29.6 \mathrm{mg}$ sample of $C$. calothyrsus leaf extract was 156 ppm (Setyawati et al., 2019). This antioxidant activity value proved that $C$. calothyrsus was a potential antioxidant. According to Fitmawati et al. (2017), this antioxidant activity value is moderate base on the antioxidant activity criteria.

The results of our study showed an interesting phenomena that should be further investigate. The 
extract-treated rats showed a decrease estrogen level if the animals were given higher dose of $C$. calothyrsus leaf extract. Estrogen reached the highest level in dose $17.5 \mathrm{mg} / \mathrm{kg}$ bw (Table 1). The decrease of estrogen level in higher doses in this study maybe because the extract also affected progesterone level. We know that estrogen and progesteron play different role in the female reproduction. According to AlSabbagh et al. (2012), estrogen promotes epithelial proliferation so the endometrium thickens during proliferative phase of estrous/ menstrual cycle, then progesterone prevent estrogen-induced proliferation and enable stromal cells to launch decidualization process during the secretory phase.

The results on uterus wall thickness in our study showed that the increase dose of $C$. calothyrsus leaf extract made the increase thickness of all uterus layers namely endometrium, myometrium and perimetrium. The highest dose of $70 \mathrm{mg} / \mathrm{kg}$ bw of $C$. calothyrsus leaf extract gave the thickest size in each layer. Therefore, $C$. calothyrsus extract can be considered as herbal medicine or drug candidate (with further preclinical research) to improve uterine wall especially endometrial thickness (due to successful embryo implantation) without huge increase of estrogen level. In females, a spike of estrogen level should be considered, because it can affect other reproductive hormones such as progesterone, FSH, and LH. According to Hamilton et al. (2017), excess estrogen level is also suspected to cause higher risk of cancer or other estrogenrelated diseases in women.

\section{CONCLUSION}

In this study, administration of C. calothyrsus leaf extract increased estrogen hormone concentrations. The effective dose of C. calothyrsus leaf extract on uterine wall thickness was $70 \mathrm{mg} / \mathrm{kg}$ bw because it did not reduce uterine weight, and maintained the diameter and thickness of endometrium, myometrium and perimetrium layers remained normal like control rats.

\section{ACKNOWLEDGEMENT}

Authors would like to thank to Faculty of Mathematics and Natural Sciences and LPPM Udayana University for the financial support with PNBP Fund 2019 (Agreement Number 2002/UN14.2.8..II/LT/2019).

\section{REFERENCES}

Abd-Elkareem. (2017). Morphological, histological and immunohistochemical study of the rabbit uterus during pseudopregnancy. Journal of Cytology \& Histology, 8, 443.

Al-Sabbagh, M., Lam, E. W., \& Brosens, J. J. (2012). Mechanisms of endometrial progesterone resistance. Molecular and Cellular Endocrinology, 358(2), 208-215.

Ameer, M.A., Fagan, S. E., \& Sosa-Stanley, J. N. (2021). Anatomy, abdomen and pelvis, uterus. StatPearls Publishing.

Barrett, K. E., Barman, S. M., Brooks, H. L. \& Yuan, J. (2019). Ganong's Review of Medical Physiology. $26^{\text {th }}$ Edition. Mc. Graw Hill Book.

Chung, D., Gao, F., Jegga, A. G., \& Das, S. K. (2015). Estrogen mediated epithelial proliferation in the uterus is directed by stromal Fgf10 and Bmp8a. Molecular and Cellular Endocrinology, 400, 48-60.

Constantine, G., Millheiser, L. S., Kaunitz, A. M., Parish, S. J., Graham, S., Bernick, B., \& Mirkin, S. (2019). Early onset of action with a $17 \beta$ estradiol, softgel, vaginal insert for treating vulvar and vaginal atrophy and moderate to severe dyspareunia. Menopause, 26(11), 1259-1264.

Fitmawati, Sofiyanti, N., Roza, R. M., Isnaini, Irawan, Y. R., Winata, D. R., \& Dewi, A. P. K. (2017). Antioxidant activity of dominant plants species in obat pahit from lingga malay ethnic in riau archipelago. Biosaintifika: Journal of Biology \& Biology Education, 9(2), 325-331.

Gultom, Y. N. (2001). Efektivitas penyuntikan PMSG sebelum perkawinan induk pada bobot organ dan ukuran tubuh anak tikus putih usia lepas sapih [Unpublished thesis]. Institut Pertanian Bogor.

Hall, J. (2015). Guyton and Hall Textbook of Medical Physiology, $13^{\text {th }}$ Edition, Saunders Publisher.

Hamilton, K. J., Hewitt, S. C., Arao, Y., \& Korach, K. S. (2017). Estrogen hormone biology. Current Topics in Developmental Biology, 125, 109-146.

Holesh, J. E., Bass, A. N., \& Lord, M. (2021). Physiology, ovulation. StatPearls Publishing.

Johnson, M. H. (2018). Essential Reproduction, 8th Edition. Wiley-Blackwell.

Kelleher, A. M., Burns, G. W., Behura, S., Wu, G., \& Spencer, T. E. (2016). Uterine glands impact uterine receptivity, luminal fluid homeostasis and blastocyst implantation. Scientific Reports, 6, 38078.

Kota, S. K., Gayatri, K., Jammula, S., Kota, S. K., Krishna, S. V. S., Meher, L. K. \& Modi, K. D. (2013). Endocrinology of parturition. Indian Journal of Endocrinology and Metabolism, 17(1), 50-59.

Kumar, P., \& Sait, S. F. (2011). Luteinizing hormone and its dilemma in ovulation induction. Journal of Human Reproductive Sciences, 4(1), 2-7. 
Lephart, E. D. (2015). Modulation of aromatase by phytoestrogens. Enzyme Research, Article ID 594656. https://doi.org/10.1155/2015/594656

Mardika, K., Setyawati, I., \& Darmadi, A. A. K. (2018). Panjang siklus estrus dan struktur histologi ovarium tikus putih setelah pemberian ekstrak etanol daun kaliandra merah. Jurnal Veteriner, 19(3), 342-350.

Marquardt, R. M., Kim, T. H., Shin, J. H., \& Jeong, J. W. (2019). Progesterone and estrogen signaling in the endometrium: what goes wrong in endometriosis?. International Journal of Molecular Sciences, 20(15), 3822.

Narulita, E., Prihatin, J., \& Dewi, R. S. (2016). Pemanfaatan hasil induksi hormon estrogen terhadap kadar estradiol dan histologi uterus mencit (Mus musculus) sebagai buku suplemen sistem reproduksi di SMA, Jurnal Bioedukatika, 4(2), 1-7.

Onyeama, H. P., Ibekwe, H. A., Ofemile, P. Y., Peter, A., Ahmed, M. S., \& Nwagbo, P. O. (2012). Screening and acute toxicity studies of calliandra portoricensis (eri agbo in igbo) used in the treatment of snake bite in south eastern nigeria. Vom Journal of Veterinary Science 9, 17-24.

Paterni, I., Granchi, C., Katzenellenbogen, J. A., \& Minutolo, F. (2014). Estrogen receptors alpha $(\mathrm{ER} \alpha)$ and beta (ER $\beta)$ : subtype-selective ligands and clinical potential. Steroids, 90, 13-29.

Resende, F. A., de-Oliveira, A. P. S., de-Camargo, M. S., Vilegas, W., \& Varanda, E. A. (2013). Evaluation of estrogenic potential of flavonoids using a recombinant yeast strain and MCF7/BUS cell proliferation assay, PLoS One, 8(10), e74881.
Rietjens, I. M., Sotoca, A. M., Vervoort, J., \& Louisse, J. (2013). Mechanisms underlying the dualistic mode of action of major soy isoflavones in relation to cell proliferation and cancer risks. Molecular Nutrition \& Food Research, 57(1), 100-113.

Roberts, H, \& Lethaby, A. (2014). Phytoestrogens for menopausal vasomotor symptoms: a cochrane review summary, Maturitas, 78(2), 79-81.

Schweikart, K. M., Eldridge, S. R., Safgren, S. L., Parman, T., Reid, J. M., Ames, M. M., Goetz, M. P., \& Davis, M. A. (2014). Comparative uterotrophic effects of endoxifen and tamoxifen in ovariectomized sprague-dawley rats. Toxicologic Pathology, 42(8), 1188-1196.

Setyawati, I, Wijayanti, N. P. A. D., \& Wiratmini, N. I. (2019). Phytochemical content, extract standardization and antioxidant activity of Calliandra calothyrsus Meissn leaf, a potential phytoestrogen source, IOP Conference Series: Earth and Environmental Science, 347, Article 012075.

Thomas, C., \& Gustafsson, J. Å. (2011). The different roles of ER subtypes in cancer biology and therapy, Nature Reviews Cancer, 11(8), 597-608. https://doi.org/10.1038/nrc3093

Thiyagarajan, D. K., Basit, H., \& Jeanmonod, R. Physiology, menstrual cycle. StatPearls Publishing.

Widhayanthi, T. A., Pangkahila, W., \& Pinatih, G. N. I. (2017). Pemberian suplemen swissoats A3® meningkatkan kadar hormon estrogen pada tikus (Rattus norvegicus) betina menopause galur wistar, Jurnal Biomedik, 9(2), 75-81. 